13. Samchuk, U. (1957). Temnota: Roman v 2 ch. New York: Ukrainska Vilna Academia Nauk v SSHA. [in Ukrainian].

14. Stepanov, A. (2005). Probliemy kommunikatsii u Chebova. Moskva: Yazyki slavianskoi kultury. [in Russian].

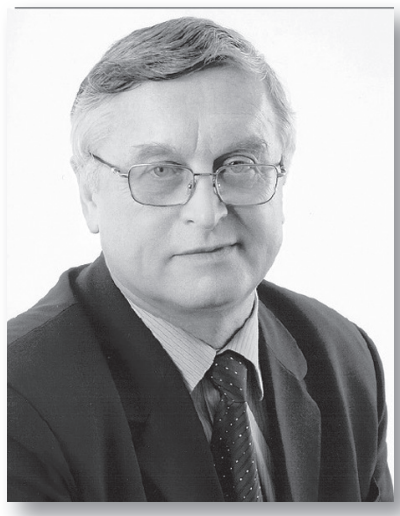

Степан Іванович Хороб - літературознавець, театрознавець, журналіст, педагог. Здобув науковий ступінь кандидата філологічних наук (Одеса, 1989), доктора фрілософії в Українському Вільному Університеті (Мюнхен, 1997) і доктора фолології габілітованого (Мюнхен, 1999), доктора філологічних наук у Львівському національному університеті імені Івана Франка (2002); звання профресора отримав у 2003 р.

Після закінчення фрілологічного фракультету ІваноФранківського педагогічного інституту імені Василя Стефраника (1971) працював учителем, журналістом у редакціях газет Івано-Франківщини, а від 1987 р. асистент, старший викладач, доцент кафедри української літератури, з 1994 р. до сьогодні - завідувач кафредри української літератури Прикарпатського національного університету імені Василя Стефраника; у 2006 - 2013 рр. - директор Інституту філології Прикарпатського національного університету імені Василя Стефаника. Член Національної Спілки письменників України, Національної Спілки журналістів України, відмінник освіти України (2005), дійсний член НТШ (2003), заслужений діяч науки $і$ техніки України (2009). Степан Хороб - голова спеціалізованої вченої ради із захисту кандидатських дисертацій у Прикарпатському національному університеті імені Василя Стефраника та член спеціалізованої ради із захисту докторських дисертацій у Львівському національному університеті імені І. Франка.

Степан Хороб - автор понад 250 наукових праць, серед них десятки книжок: "Українська драматургія: крізь виміри часу (теоретичні та історико-літературні аспекти драми)” (1999), “Слово-образ-форма: у пошуках художності. Літературознавчі cmammi і дослідження" (2000), "Українська релігійна драма кінця XIX - початку XX століття: проблематика, жанрово-стильова своєідність" (2001), "Українська модерна драма кіния XIX - початку XX столітmя (неоромантизм, символізм, експресіонізм" (2002), “Українська драматургія 20-30-х років у Західній Україні та діаспорі” (2008), "На літературних теренах: Дослідження, статmі, рецензії" (2006), "Літературномистецькі знаки життя: Літературознавчі й театрознавчі статmі, дослідження $i$ публіцистика” (2009), “Діалоги у відсвіті слова. (Українська драматургія у типологічних зіставленнях)" (2013), “Збережені миті. Cmammi, портрети, інтерв'ю, огляди, рецензії” (2015), “... Драма - моя стародавня страсть” (Драматургія і театр Івана Франка)” (2016). Він також упорядкував п'єси Г. Лужницького та В. Мельника, літературознавчі праці В. Державина, Л. Білецького, Л. Рудницького та ін. Співавтор навчального посібника “Франкова криниця (Вивчення творчості І. Я. Франка у школі)” (1991), “Історії української літератури кінця XIX - початку XX століть": У 2 кн. - Кн. 2. (2006), "Історії української літератури у 12 m." (томи 7 і 8), близько тисячі публіцистичних виступів у засобах масової інформації. Друкувався в літературознавчих виданнях Мюнхена (Німеччина), Варшави й Кракова (Польща), Оломоуча (Чехія), Філадельфії (США), Пряшева (Словаччина), Мінська (Білорусь), Вінніпега (Канада), Загреба (Хорватія). 


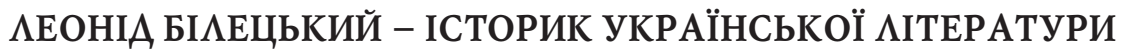

У статті досліджено історико-літературні концепції літературознавчих праць відомого українського вченого з діаспори Леоніда Білецького. На обширному матеріалі його студій з українського письменства, написаних здебільшого в еміграції, їх проаналізовано крізь авторську методологію вивчення ідейно-естетичних явищ національної літератури; виявлено її прикметні риси, специфічні принципи та погляди на існування й розвиток історико-літературного процесу через факти, зміни, художні персоналії тощо. Для дослідження поставленої мети й завдань використано фрілологічний, порівняльно-історичний та генетичний методи. Це дало змогу проаналізувати специфіку поглядів Леоніда Білецького як історика національного письменства, починаючи від його навчального підручника “Історія української літератури”, що є своєрідною енциклопедією національної культурно-історичної духовності нашого народу, і завершуючи цілою низкою "портретових історій" багатьох письменників давнього, нового і новітнього українського письменства.

Ключові слова: історія української літератури, методологічні концепції Леоніда Білецького, літературознавство еміграції, жанр, стиль.

\section{Stepan Khorob. Leonid Biletskyi as Historian of Ukrainian Literature}

The paper deals with historical and literary concepts in the works of the Ukrainian scholar from diaspora Leonid Biletskyi based on the extensive material of his studies on the Ukrainian literature. Using philological, comparative historical and genetic methods the author of the paper analyzes these concepts in the light of Biletskyi's methodology of studying the ideological and aesthetic phenomena of a national literature that includes revealing characteristic features, specific principles and views on the existence and development of the literary process. This method allows outlining specificity of Leonid Biletskyi as a historian of the national literature, noticeable in his textbook "The History of Ukrainian Literature", being a kind of encyclopedia of the national cultural and historical spirituality of Ukrainians, as well as in a series of the 'portrait stories' presenting many writers of the old, new and contemporary literature.

The paper reveals and systematizes historical and literary approaches of the scholar to studying literary and artistic phenomena, processes and certain works. The literary critic evaluated every ideological and aesthetic phenomenon of the national literature based on the general literary criteria. His analysis started from the form (genre, style, stylistics), as, according to the researcher, the form renders the development of the literary process, in which only the core of the author's artistic thinking a man and his being - remains unchanged. At the same time Leonid Biletskyi grounded his estimation of the writer's works and creativity not only on the development of the national literature, but also on the changes in social consciousness of the time. Thus, as a historian of literature, he managed to combine in his scholarly thinking the subjectivity and objective development of the literary process.

The historical concepts of Leonid Biletskyi haven't been studied sufficiently yet. The present paper offers the first review and systematization of them and aims at revealing the special views of the emigration scholar on the development of the Ukrainian literature.

Keywords: history of Ukrainian literature, methodological concepts, Leonid Biletskyi, literary studies of diaspora, genre, style.

Серед представників українського літературознавства з діаспори Леонід Білецький (1882 - 1955) посідає чільне місце як історик літератури та літературної критики, творець методологічних концепцій у дослідженнях вітчизняного письменства, як фольклорист і театрознавець тощо. Хоча материкове літературознавство до початку 1990-х років це прізвище майже не згадувало, усе ж воно так чи так проникало до рідкісних і доволі упереджених з ідеологічного погляду публікацій та видань, як це здебільшого спостерігалось при згадках про інших видатних українських філологів еміграційного літературознавства - Д. Чижевського, Ю. Лавріненка, Ю. БойкаБлохина, І. Кошелівця та ін. У 1997 р. М. Наєнко видав книжку "Українське літературознавство", де вперше на материковій Україні було осмислено внесок Л. Білецького в науку про літературу. Ім'я Л. Білецького варто було б знати чи покликатися на його праці вже хоча б тому, що він був творцем 
історії її української літературознавчої думки, перший систематизовано виклав психологічну теорію О. Потебні, перший спробував систематизувати концепти літературно-наукової методології літературознавчої критики. Отже, закономірним було прагнення сучасних дослідників якомога скоріше перевидати праці вченого з діаспори в незалежній українській державі. Зокрема, М. Ільницький у 1998 р. в серії “Літературні пам'ятки України” впорядкував і науково відредагував унікальну працю Л. Білецького "Основи української літературно-наукової критики”, яка побачила світ ще далекого 1925 р. в Празі як перший том запланованого фундаментального дослідження про природу, естетичну специфіку й функціонування української літературно-наукової критики. Уже на початку нового XXI ст. почастішали покликання на інші статті й студії цього вченого - чи то в тритомній "Хрестоматії українського літературознавства і критики”, чи то в нових “Історіях української літератури”, чи то в розвідках про творчість окремих письменницьких постатей (приміром, Т. Шевченка, І. Франка, Марка Вовчка, Лесі Українки, О. Кобилянської) або ж у працях, присвячених розвитку українського фольклору й театрального мистецтва.

Однак цього явно недостатньо, щоб мати об'єктивне уявлення про різносторонність Л. Білецького як ученого, науковця європейського рівня. Адже досі не лише більш-менш обізнаний з історією української літературознавчої думки фрілолог, а й ціла низка науковців молодшого покоління не знають таких важливих з погляду історії, методології, теорії й критики праць авторитетного дослідника, як “Поезія і критика” (1921), "Українська драма” (1923), “Перспективи літературно-наукової критики” (1924), “Сумцов як історик літератури” (1925), "Гайдамаки" Шевченка" (1930), "Історія української літератури: Фольклор" (1937, 1947), “Дмитро Дорошенко” (1949), “Віруючий Шевченко” (1949), “Омелян Огоновський” (1950), "Три сильветки: Марко Вовчок, Ольга Кобилянська, Леся Українка" (1951), “Світогляд Шевченка" (1952), “Романтизм Шевченка” (1953), "Естетика Шевченка" (1954), “Композиційна форма поезій Шевченка" (1954).

Цілий літературознавчий корпус невідомих широкому загалу (почасти й фахівцям) наукових праць ученого з української діаспори ще чекає на своє вивчення й осмислення. Особливо ті численні дослідження, що дотичні до історії української літератури, її методологічних концептів, її персоналій і їхніх творів. Адже за твердженням М. Мандрики, автора літературно-критичного нарису "Леонід Білецький" (Вінніпег, 1957), учений, який закінчив історикофілологічний факультет Київського університету Святого Володимира, тривалий час був учнем відомих київських професорів В. Перетца й А. Лободи саме як історик літератури. А 1918 р., склавши магістерський іспит з відзнакою, був залишений при університеті як науковий співробітник кафедри словесності. Незабаром був габілітований на приват-доцента Кам'янець-Подільського університету (ректором якого був професор І. Огієнко), де викладав здебільшого історію українського письменства й фольклор. Після поразки УНР Л. Білецький переїздить до Львова, де впродовж 1921 - 1923 рр. викладає історію української літератури в Українському таємному університеті. Після заборони університету польською окупаційною владою він 1923 р. переїздить до Праги, де на запрошення керівництва Українського громадянського комітету стає ректором Українського педагогічного університету ім. М. Драгоманова (1923 - 1926), водночас викладаючи там українську літературу й фольклор. 31925 р. він стає приват-доцентом кафедри української літератури, а 3 1932 р. - професором кафедри українського права в галузі дослідження старовинних пам'яток Українського вільного університету, де працював до 1945 р. Також він викладає українську літературу в Українській гімназії в Празі, 
в Українській господарській академії в Подєбрадах, а кількома роками раніше здобуває ступінь доктора фрілософії в Карловому університеті, що дало йому право здійснювати виклади літературознавчих дисциплін у різних навчальних закладах як на території Чехії, так і в Ульмі та Мюнхені, де він до переселення у Вінніпег 1949 р. переважно був викладачем української літератури, фольклору та культури.

Ми зумисне навели такі штрихи з біографії Л. Білецького, щоб наголосити на його активній участі в написанні праць з історії рідного національного письменства й у викладанні його основ розвитку в різних навчальних закладах не лише в Україні, а й за її межами. Зрештою, свою наукову працю як історик літератури учений розпочав, ще навчаючись у Київському університеті, статтею “До літературної історії повісті про Меркурія Смоленського" (1914), немовби визначаючи подальші наукові зацікавлення з давньоукраїнського письменства. Хоча вже 1918 р. дослідження "Виховання емоціонального образного мислення і твори Т. Шевченка", а також "Народність чи національність у творах Т. Шевченка" (1919) поклали початок шевченкознавчим студіям Л. Білецького, а отже, розробці системних поглядів ученого на історію розвитку української літератури. Прикметною тут є написана на початку 1920-х років перша істориколітературна розвідка дослідника "До питання про початок історії української літератури". По суті, тоді ж з'явилася низка його літературно-критичних і теоретичних статей про У. Кравченко, М. Коцюбинського, М. Вороного, В. Гнатюка, К. Поліщука, а також творчість раннього П. Тичини (“Естетика сучасної поезії і творчість П. Тичини").

І все ж, на думку М. Ільницького та М. Наєнка, чи не найпродуктивніший період Л. Білецького як історика національного письменства припадає на час його перебування у Празі. Власне, тут він остаточно сорормувався як історик українського літературознавства та української літератури, створивши цілу низку важливих наукових досліджень, зокрема "Москалева криниця" Шевченка" (1923), "Українська драма" (1923), “Перспективи літературно-наукової критики" (1924), “Основи літературно-наукової критики” (1927), "Історія української літератури: Фольклор” (1937), урешті, саме тут викристалізовувалися його підходи (концепти й методологія) до аналізу ідейно-естетичних категорій критики, художніх явищ національного письменства та національного театру. Водночас погляди дослідника на літературознавчі й літературні явища постійно вдосконалювалися ще й завдяки участі в діяльності Українського інституту громадознавства, що з 1920-х років існував у Празі. Там він активно проводить науково-методологічні семінари, наукові конференції та зустрічі з чеськими (здебільшого з Карлового університету) ученими-фрілологами. Доречно зазначити, що на таких семінарах Л. Білецький виступав із ґрунтовними доповідями, які засвідчували глибину й обшири його наукових зацікавлень: "Роль і місце соціологічного студіювання літератури в загальній літературнонауковій критиці", "Соціологічна теорія ідеалістичної літературно-наукової критики", "Історія літератури - система методологічних концепцій” та ін. А в таких виданнях того часу, як "Літературно-науковий вістник", "Нова Україна", "Студентський вісник", "Самостійна думка", “Наукові записки НТШ”, учений опублікував чимало історико-літературних праць, фольклорних студій, досліджень з історії драматургії й театру. Загалом у цей "празький" період він постав як надзвичайно продуктивний літературознавець й активний учасник українського літературно-мистецького життя за кордоном (укладав хрестоматії та антології національного письменства, писав передмови до видання творів українських авторів, оглядові статті, рецензії тощо). 
1945 р. з приходом до Праги радянських військ Л. Білецький змушений був залишити це місто й перебратися до Баварії, до міста Ульм, яке контролювали американські війська, поселення, що було в англійській окупаційній зоні, де перебували тисячі українських біженців. Там вони перебували у своєрідних таборах ДіПі (переміщені особи), між якими існували тісні контакти не лише у сфері повсякденного побутування, а, що особливо, у сфері національнокультурній: діяли недільні школи, працювали мистецькі клуби, виникали редакції газет, засновувалися видавництва, нарешті, саме в Баварії, зосібна в місті Мюнхені, був створений відомий МУР - літературно-мистецьке угрупування "Мистецький український рух". У всіх цих виявах українства на німецьких землях брав активну участь Л. Білецький, передовсім як викладач українського фольклору й національного письменства, автор літературнокритичних розвідок і рецензій. Важливо зауважити, що вчений упродовж кількох років перебування на теренах Західної Німеччини чи не найбільше співпрацював із Центральним представництвом української еміграції (ЦПУЕ), насамперед із відділом культури і освіти при ньому. Спільно з ним він складає програму освіти в табірних умовах, котра передбачала створення садків, народних шкіл, гімназій, музично-театральних шкіл, натуральних курсів, а також вищих шкіл - Українського вільного університету, Української богословської академії тощо.

Загалом, незважаючи на умови і труднощі реалізації цих програм, вони були виконані якщо й не повністю, то в основних пунктах. I стосується це уніфікації навчальних планів українського шкільництва, виконавши які та склавши відповідні натуральні екзамени, юнаки і дівчата українського походження могли вільно вступати до німецьких університетів, семінарій, академій. Вочевидь ішлося тут не так про фахові знання, як про входження через освіту й науку української молоді до загальноєвропейської освітньої системи, до досягнення нею культурно-духовних цінностей Європи. Із цього приводу Л. Білецький так писав в одному зі своїх звітів про здійснену організаційну й навчальну роботу: "Умови для шкільництва не були сприятливі. Але виявилася позитивна риса нашого народу - в найтяжчих умовах змагання до освіти, до піднесення виховання дітей і їх культури. За рік діти змінялись до невпізнання: поведінкою, мовою, інтересом до знання. Підтримка всіх організацій і навіть церков: грекокатолики й православні в однім клясі, приятельство, спільна праця серед дітей, учительства й отців катехитів. Спільні відправи на початку шкільного року, повна толеранція, взаємна пошана. Надпартійний виховний напрям: у християнському дусі, загальнонаціональнім і поборницьким" [5, 12-13].

Безперечно, як директор Української гімназії в Ульмі й викладач історії української літератури, культури і фольклору, з одного боку, а також як референт та голова ЦПУЕ, з другого - Л. Білецький у справі виховання молодих українців чи загалом українських емігрантів виявляв надзвичайну працездатність, цілеспрямованість і далекоглядність. Він зчаста акцентував на тому, що за молоддю - майбутнє України, що вона має бути освіченою, європейськи заангажованою й своїми повсякчасними діяннями має утверджувати "українську національну самість та самоцінність".

Власне, виходячи з таких позицій, учений вибудував свої погляди й на викладання історико-літературних та фольклорних курсів, і на створення праць про окремі письменницькі постаті та їх твори, і на написання повноцінних сторінок з історії українського письменства, усної народно-поетичної творчості. Як інші дослідники української діаспори (передовсім Д. Чижевський, Ю. Шерех (Шевельов), Л. Білецький, коли йшлося про розвиток літературнохудожнього процесу й виокремлення в ньому справжніх ідейно-естетичних 
явищ, постулював думку про те, що аналіз цього завжди треба починати 3 форми (жанр, стиль, стилістика), оскільки рух літератури, зосібна українського письменства, - це насамперед рух форми, незмінним у якій є лише епіцентр художнього мислення автора твору - людина та її буття. Згадаймо, що така концепція світобачення й світовідтворення митця чи не найбільше й найчастіше викликала заперечення офріційного радянського літературознавства, соцреалізм якого передбачав форму як орнаментальну прикрасу змісту. I не більше, адже літературна творчість неодмінно "соціалістична за змістом" і "національна за фрормою", тому, мовляв, остання не може впливати на змістове наповнення художнього твору.

Знову ж таки згадаймо, як свого часу вже інший Білецький - Олександр, що був рупором та ідейним натхненником соцреалізмівських підходів до будьяких явищ в аналізі творів української літератури, не тільки кепкував з “Історії української літератури (від початків до доби реалізму)” Д. Чижевського, а й піддавав її нещадній критиці, звинувачуючи визначного діаспорного вченого в тому, що саме він своєю історико-літературною працею, мовляв, “обезкровив історію нашої літератури”, розглядаючи (“за прикладом німецьких буржуазних літературознавців") тільки фрормотворчий вияв творів, котрий, мовляв, аж ніяк не зв'язаний ні з політикою, ні з класовою боротьбою, ні з партійною ідеологією тощо. Як справедливо зауважує з цього приводу М. Наєнко, "останнє цілком очевидно виказувало звуженість і спрощеність радянської наукової методології, оскільки відомо, що фрорми художньої творчості функціонують і змінюються не довільно, а відповідно до змін і в естетичній, і в суспільній свідомості людства, відповідно до зрушень (у широкому розумінні) в історії людської цивілізації. Саме це і мав на увазі Д. Чижевський, коли говорив у своїй “Історії...”, що для визначення вартості художніх творів і літературних періодів недостатніми будуть лише проблеми стилю, стилістики; велику роль при цьому відіграють і питання ідеологічного розвитку" [6,7].

Тому, коли знайомишся з такою історико-літературною працею Л. Білецького, як "Три сильветки: Марко Вовчок, Ольга Кобилянська, Леся Українка", що була опублікована в канадському видавництві “Тризуб” (Вінніпег, 1951) після переїзду вченого 1949 р. на постійне місце проживання до Канади, усвідомлюєш, що така концепція Д. Чижевського була органічною в середовищі, по суті, усіх діаспорних дослідників історії українського письменства. Адже і творчість Марка Вовчка, і творчість Ольги Кобилянської, і творчість Лесі Українки Л. Білецький розглядає передовсім крізь призму стильових ознак, що змінювалися разом зі змінами ідейно-естетичних орієнтирів як самих авторів, так і відповідної суспільної свідомості. І фрорма в їхніх творах, за переконанням літературознавця, посутньо визначала змістове наповнення кожного із використаного ними жанрових утворень - оповідання, повісті, роману, драматичного етюду, драматичної поеми тощо. Щодо цього цікавими $€$ висновки вченого про стильові особливості творчості названих письменниць.

Про Марка Вовчка: “<...> найвидатніше її досягнення - стиль розповіді від імені дійової особи в формі й темпі усної мови й її надзвичайна мова, що й до сьогодні ще вважається найкращою <..> Вона творить новий літературний жанр: соціальну повість, що пізніше так широко позначилася в українському письменстві < ..> Етнографічно-побутовий реалізм Квітки й Куліша доведений у Марка Вовчка до повного його вивершення. Тільки реалістична школа Свидницького і Нечуя-Левицького в українській літературі поглибила стильову манеру Марка Вовчка" [2, 21-22]. Про Ольгу Кобилянську: “< .. > як письменниця вона $€$ найсильніша повістярка й новелістка з усіх жінок цілої слов'янщини. В українській літературі О. Кобилянська започаткувала новий стильовий 
напрям - неоромантизм. Першою стає в оборону української в літературі жінки. В розробленні характерів і ситуацій - найглибший психолог і фрілософ у літературі <...> Створила найталановитіший жанр повісті (ідеться про фрорму і структуру “Землі” - Л. Б.), що й до сьогодні стоїть у ряді найвидатніших повістей в українській літературі" [2, 74].

Про Лесю Українку: “Леся Українка в українській літературі найсильніший неоромантик, що виявилося в її ліриці, в поемі і в глибоко національній драмі, і вершина цього стильового багатства - її незрівняна “Лісова пісня". Леся Українка, як і Ольга Кобилянська, свідомо виводила українську літературу 3 обмеженого кола свого існування в безмежні простори світової літератури, 3 нею разом і ті національні ідеї визвольної боротьби України бути паном своєї землі і багатющої культури" [2, 126-127].

Як переконуємося, формотворче, зосібна стильове означення творів Марка Вовчка, Ольги Кобилянської та Лесі Українки Л. Білецький як історик української літератури виводив не лише з розвитку національно-художнього літературного процесу, а й зі змін тодішньої суспільної свідомості.

Таке поєднання “суб'єктивності” й “об'єктивності” в цьому русі - своєрідний закон, що характеризує поступ не тільки мистецтва слова, а й сценічного, музичного мистецтва, не лише національного письменства, а й світової літератури. Отже, на думку вченого, завдання історика літератури й полягає у тому, щоб вписати її в цю закономірність через дослідження окремих (естетично визначних) письменницьких постатей. Зрозуміла річ, таке завдання Л. Білецький у своїй історико-літературній праці “Три сильветки: Марко Вовчок, Ольга Кобилянська, Леся Українка" виконував не механічно, звівши довільно творчість трьох письменниць-жінок до пошуків ними стильових самовиражень, а виходив насамперед із цілковитої відповідності їхніх творів до етапів розвитку загальноукраїнського літературного процесу та їх стильових домінант - реалізм, психологічний реалізм, модернізм з його розгалуженнями неоромантизму й символізму. Унаслідок такої концепції дослідження названих жінок-письменниць Л. Білецький не лише окреслив формальні особливості їхньої прози, поезії й драматургії, зокрема їх стильових ознак, а й максимально відтворив специфіку духу української літератури, яка завдяки Марку Вовчку, Ользі Кобилянській та Лесі Українці виборола суверенне право нашого національного письменства в колі світової літератури.

Перебравшись до Вінніпега, ці погляди на розвиток української літератури Л. Білецький щораз розширював, удосконалював їх методологію. Тут, у цьому канадському місті, де мешкало тоді кількасот українців, він працював в "Осередку культури й освіти" як член дирекції, а згодом у редакції газети "Український голос" (від 1951 р.) і як директор "Ради української школи" в "Союзі українців-самостійників". Та найплідніша праця його все ж була в Українській вільній академії наук, яку очолював професор Д. Дорошенко, а після його смерті 1951 р. - Л. Білецький. Власне, цю наукову посаду він обіймав до кінця своїх днів. Однак саме робота в УВАН сприяла реалізації його творчих планів, серед яких одним із найважливіших (і найдавніших) була підготовка й видання творів Т. Шевченка за "власними принципами впорядкування та коментарями” (М. Ільницький). Це історико-літературне завдання вчений виконував надзвичайно сумлінно й прискіпливо до першодруків Кобзаря упродовж кількох літ. Починаючи з 1952 р. і завершуючи 1954 р., за фрінансової підтримки видавництва "Тризуб” вийшло чотири томи творів Т. Шевченка як видання УВАН. Останній, п'ятий том, він уже не побачив: помер 5 лютого 1955 р. У 2013 р. Р. Радишевський видав тритомник наукових праць “Леонід Білецький. Шевченкіана". 
Історико-літературна праця Л. Білецького - видання, упорядкування й науковий коментар до неї, а також до кожного тому спеціально написані ним вступні та загальні коментарі - уже сама по собі викликала різні думки, іноді суперечливі, почасти й заперечувальні. I не тільки в діаспорному середовищі, а й серед шевченкознавців материкової України. Усе пояснювалося незвичністю підходу вченого до подачі творів Т. Шевченка, а тому і до кінця незрозумілою концепцією їх структурування. Саме цим видання творів поета різнилося від інших, попередньо виконаних упорядкувань (до речі, як на еміграції, так і в УРСР). Як пише Б. Романенчук у своєму “Азбуковнику", така "редакція примітна тим, що Шевченкові поетичні твори упорядковані не хронологічно, як попередньо, а циклічно, за окремими циклами, відповідно до поетового душевного стану, в якому виявилася його велика творча сила, або відповідно до місця, де поет перебував і писав вірші" [7, 343]. Вочевидь, на такий підхід ученого спонукав сам Т. Шевченко, який групував свої поезії в художньо та ідейно-естетично викінчені цикли. "Крім того, упорядник прийняв засаду, відмінну від традиційної, першодруку Шевченкових поезій, цебто першу редакцію, а не останню, як робили попередники, - зазначав Б. Романенчук. Ця засада, на його думку, має ту перевагу, що перша редакція найщиріша і найбезпосередніша, вона передає якнайвірніше поетові настрої й переживання в хвилі їх появи, а пізніше поправки і зміни відбиваються уже інші, пізніші настрої й міркування, які, мабуть, і були спокусою до змін” [7, 343].

За свідченням цілої низки шевченкознавців і передовсім Л. Білецького, такі пізніші від першодруку поправки, що їх уносив сам автор чи редактор, не завжди були доречними в тих або тих віршах; іноді вони й видозмінювали твір, спростовуючи в такий мимовільний спосіб первісний задум поета. Має рацію Б. Романенчук, який у своїй статті про Л. Білецького зауважує: традиційний погляд дослідників на те, що пізніша редакція першодруку незрідка буває досконалішою від початкової, а тому для наукового видання важливішою, викликав спротив у вченого. I він доводив, що такий погляд неправильний, адже Т. Шевченко зчаста робив "поправки в свої творах не так з естетичних міркувань, як радше з речових, які на мистецький рівень не мали впливу". Тому-то логічним сприймаються прагнення Л. Білецького до кожного циклічного групування творів поета подавати пояснювальні статті, що мотивують появу кожного циклу поезій, і надавати інформацію "про історію кожного циклу, історію тексту, видань, речевий склад і постання, а після тексту загальну внутрішню історію циклу, характеристику й літературно-ідеологічну інтерпретацію" [7, 343].

Щодо інтерпретації, то з Л. Білецьким не завжди в усьому можна погодитися, бо він беззастережно як апріорний суспільно-політичний підхід в аналізі поетичних творів Т. Шевченка (включаючи й ті, що не були вислідом будьяких суспільних чи політичних розмислів) узяв як наскрізну концепцію впорядкування та наукового редагування. Тим часом не всі поетичні твори можна пояснити, виходячи з таких позицій. Приміром, поема "Катерина", що з'явилася ще 1840 р. в першому виданні "Кобзаря", аж ніяк не написана 3 соціально-політичних позицій, а радше з позицій співчутливих до людського горя, людської трагедії. То вже згодом, коли поет, переживши чимало власних потрясінь, збагнувши глибинні пласти національної історії, суспільну трагедію поневолення українців, зусібічно усвідомить те, що, власне, й зробило його національно-політичним речником і пророком українського народу. За справедливим висновком Б. Романенчука, такий “політичний підхід до всього Шевченка привів дослідника до того, що він бачив у “Катерині” два протилежні світогляди, два протилежні національні типи, що себе взаємно виключають, а у взаємних стосунках ведуть неминуче до конфлікту й катастрофи, у якій 
завжди гине слабший, хоч в основі своїх духовних властивостей виявляє глибшу натуру, суцільну й послідовнішу, а в своїй душі носить "вищу правду". Погляд цей не витримує критики, хоч він дуже патріотичний” [7, 344].

Л. Білецький в інтерпретації деяких творів Шевченка подав доволі переконливий образ поета. Він справедливо вважав його романтиком від першого до останнього твору. Однак учений трактував шевченківський романтизм не як стильову ознаку, а як світоглядну категорію, що всуціль пронизує всі його твори - як раннього, так і пізнішого періодів. Тому літературознавець не погоджується з твердженням окремих шевченкознавців про те, що наприкінці свого життя поет став переконаним реалістом. Проте це правда лише з одного боку, коли мова йде про реалізм Шевченка як світоглядну засаду; з другого боку, коли дивитися на твори Шевченка крізь призму реалістичного напряму в літературі того часу, то можемо запримітити, що чимало з них написані з використанням реалістичного типу художнього мислення й відображають реальний стан засобів ідеалізації.

Варто зауважити, що в усіх чотирьох томах Л. Білецький дотримується виробленої ним самим історико-літературної концепції: до першого тому він включив поезії ранньої доби, коли Шевченко перебував у Петербурзі, до другого тому ввійшли всі найважливіші політичні, історичні й біографрічні твори, написані в часи перебування поета в Україні, до третього тому упорядник включив ті поетичні твори, що були створені Шевченком упродовж перших чотирьох років заслання (1847 - 1850). І, нарешті, до останнього, четвертого, тому були залучені всі твори Шевченка, написані в 1857 - 1861 рр., тобто в останній період його творчості. До кожного з томів Л. Білецький подав вступні й завершально-пояснювальні статті (скажімо, "Шевченко й Україна", "Шевченко й Кирило-Мефодіївське братство", "Вина і кара Шевченка", "В казематі”, “Світогляд Шевченка”, "Романтизм Шевченка”, “Естетика Шевченка”, “Композиційна форма поезій Шевченка").

Повторюємо, таку історико-літературну концепцію впорядкування не всі сприймали однаково. Наприклад, радянські шевченкознавці негативно оцінювали це видання й такі підходи Л. Білецького в подачі творів Тараса Шевченка. Наприклад, “Шевченківський словник”, що вийшов у двох томах 1976 р. в Києві, так писав про це: “Тенденційно готував літературну спадщину Шевченка й редактор чотиритомного “Кобзаря” Л. Білецький (Канада, 1952 1955). Для видання прикметна відмова від остаточно опрацьованих, старанно вивірених і виправлених текстів, які призначив до друку сам поет, надавши їм вищої ідейно-художньої довершеності й тим зафріксувавши свою остаточну творчу волю. Редактор, виходячи з хибних уявлень про творчий процес Шевченка, подав тексти поета в ранніх варіантах, довільно вважаючи їх “кращими" [8, 119]. Таку позицію можна поділяти чи, навпаки, заперечувати, однак сам факт появи науково відредагованих творів Шевченка в чотирьох томах, з одного боку, засвідчує цілком природне бажання Л. Білецького ознайомити українського еміграційного читача з творчою спадщиною, а 3 другого - виявляє його самостійну історико-літературну концептуалізацію ідейно-естетичних явищ українського національного письменства, зокрема класичної спадщини.

Тому має рацію М. Ільницький, коли стверджує, що “принцип, яким керувався Л. Білецький при підготовці поетичних творів Шевченка, не можна вважати найоптимальнішим, але він цілком можливий як один із варіантів, що дає можливість простежувати психологію творчого процесу поета" [3, 36]. За нинішніх вимог українського літературознавства такі погляди, такі підходи до оцінок історичних та літературно-художніх явищ безумовно зацікавлять 
сучасного історика українського письменства. Як, зрештою, зацікавлять його й методологічні судження діаспорного вченого, основні засади яких він здебільшого систематизував упродовж багатьох літ у струнке вчення про методологічні концепції, передовсім української літературно-наукової критики. Доречно зауважити, що в їх основу покладено лекційні виклади, які Л. Білецький подавав для студентів різних університетів - Києва, Кам'янця-Подільського та Львова, що стали головними в побудові ним фундаментальної праці “Основи української літературно-наукової критики (Спроба літературно-наукової методології)". А його естетична концепція, яку вчений використовував у своїх історико-літературних дослідженнях, чи не найґрунтовніше розроблена в такій розвідці, як "Перспективи літературно-наукової критики".

Про ці та інші праці Л. Білецького в галузі методології літературнонаукової критики, ії̈ історії й теорії в національному літературно-художньому процесі ґрунтовні статті написав М. Ільницький, зокрема "Критики і критерії: Літературно-критична думка в Західній Україні 20 - 30-х рр. XX ст.” [3, 32-51] та "Леонід Білецький - історик українського літературознавства "[4, 7-26]. Тому ми свідомо не розглядаємо їх тут, а зосереджуємося в основному на аналізі концепції та методологічних засадах діаспорного вченого як історика національного письменства.

3-поміж такого типу досліджень виокремлюється написана Л. Білецьким на основі лекційного курсу для студентів заочної форми навчання Українського технічно-господарського інституту в Подєбрадах (Чехія) в 1937 р. "Історія української літератури", а згодом доповнена й перероблена "Історія української літератури: Народна поезія" (том 1), що була видана за сприяння Українського церковного товариства в Аугсбурзі 1947 р. Цей варіант, до речі, підготовлений нами до друку. Урешті, оскільки він найповніший, тому й аналізуватимемо його особливості викладу, структури. I зробити це порівняно нескладно, якщо заглибитися в написання подібних праць інших істориків українського письменства й зіставляючи їх з "Історією..." Л. Білецького.

Тож пригадаймо, що знамениті “Історії української літератури" М. Грушевського (перші п'ять томів вийшли впродовж 1923 - 1926 рр.), С. Єфремова (перше видання побачило світ 1911 р., видання четверте з “одмінами й додатками" 1924 р.), на відміну від уже згадуваної “Історії...” Д. Чижевського, важливу увагу приділили дослідженню української ментальності ("характеристика національного типу") у подачі усної народнопоетичної творчості. Схожим шляхом пішов і Л. Білецький. Він, означивши у вступі саме поняття “література", її специфіку образності, естетичну функціональність, приналежність до загальної історії народу, природний зв'язок з народною творчістю та дохристиянською вірою й міфологією, постулює два можливі моменти - виокремлення основних епох, у яких творчо побутував український народ, а також яскравих ідейноестетичних явищ, що їх створив (самобутньо й самоцінно) цей народ упродовж багатовікової історії. Вочевидь, це й стало певною методологічною концепцією Л. Білецького: учений означився в ній як дослідник не лише "народної поезії”, а й процесу формування національного типу через розвиток його вірувань, міфологічних уявлень, перехресних упливів європейської та азійської культур на його свідомість, через його обряди, одяг, звичаї. І все це подається дослідником як вислід розвитку українського народу в певні епохи (приміром, дохристиянські, християнські, історичні тощо).

Власне, фольклору Л. Білецький, на відміну від Д. Чижевського, у якого з "самого початку дослідницької роботи усталився погляд, за яким неважко помітити певну недовіру до цього виду творчості: мовляв, несе він у собі нашарування найрізноманітніших епох і тому "чистоту експерименту" (у 
даному разі - характеристику літературного процесу) забезпечити на зможе" $[6,8]$, надавав важливого значення у формуванні не тільки психофізичного (ментального) типу, а й оригінальної літературної творчості. Згадаймо, що такої позиції дотримувався у своїх “Історіях...", наприклад, М. Грушевський, який надавав величезного значення в характеристиці “дописемного” періоду в українському літературному процесі, чи С. Єфремов, який ґрунтовно розглядав усну народно-поетичну творчість лише в “записному” вигляді й тільки в той період (час, епоху), коли він зроблений, тобто записаний.

Згідно з постульованою у вступі “Історії української літератури” позиції, Л. Білецький відповідно компонує свою "Історію..." за принципами хронологічної появи тих чи тих фольклорних явищ, їх творчого побутування в певних регіонах України, своєрідності появи та функціонування. Тому двадцять розділів, органічно й умотивовано сполучених між собою, відбито навіть у назвах: "Антропологічні, територіальні й культурні властивості українського народу”, "Український народ, його побут, вдача, звичаї й віра", "Вірування українського народу", “Обряди українського народу”, "Весняне зрівняння денне і весняні обряди", "Весняний цикл народних пісень”, "Літній зворот сонця", "Обряди осіннього зрівняння дня й ночі”, "Обряди, що не зв'язані 3 народним календарем", "Весілля", “Похоронний обряд”, “Загальне значення народних обрядів", “Головні джерела появи народної поезії”, “Народна поезія від обряду відділена", "Релігійна епічна поезія", "Українські народні думи", "Українська народна пісня як подальший мистецький розвиток української пісенної творчости”, “Пісні історичні”, “Пісні побутові”, “Стиль і ритміка пісень”.

І ще одне, що стосується методологічної концепції "Історії української літератури" Л. Білецького, яка, вочевидь, зазнала впливу вченого як дослідника української літературно-наукової критики. Бо ні там, ні там він не залучав до аналізу писемних й усних ідейно-естетичних явищ якісь нові концепції, нові методологічні підходи. Так, він був прибічником психолінгвістичної теорії О. Потебні, використовував у своїх аналітичних студіях засади фрілологічної школи літературознавства. Однак майже не сприймав нових наукових віянь, що були помітними, приміром, у часи перебування в Празі, де в 1920 - 1930-х роках діяв лінгвістичний гурток, до якого входили Я. Мукаржовський, Р. Якобсон та інші представники структурального аналізу поетичного твору. Загалом, за спостереженням М. Ільницького, це стосувалося не лише нових методологічних підходів у літературознавстві, а й різних напрямів у літературі. Власне, на такий висновок наштовхує і вступ до “Історії української літератури”, у якому Л. Білецький чітко означує прийнятні ним три головні напрями в розвитку національного письменства: класицизм, романтизм і реалізм. На його переконання, "це три найосновніші розуміння літератури як такої і в тій чи іншій формі та сполуці змінюють один одного в історії літератури аж до сьогоднішнього дня" [1, 11].

Отже, стає зрозумілим вибір історико-літературних явищ для їх аналізу Л. Білецьким: передовсім твори й постаті класичного національного письменства. Як справедливо пише М. Ільницький, дослідник упродовж усього життя так і “залишився людиною радше дев'ятнадцятого, аніж двадцятого століття, орієнтованою на високі гуманістичні ідеали й естетичні вартості мистецтва", його увагу не привертали лише ті, "чия творчість базувалася на засадах модернізму і несла з собою деструктивні тенденції” [3, 21]. Це аж ніяк не означає, що він не цікавився (ба, й писав про них) модерними віяннями, наприклад, у творчості Лесі Українки, Павла Тичини, Олександра Олеся, Ольги Кобилянської... 

науки про національне письменство.

\section{АITEPATYPA}

1. Білещъкий $\Lambda$. Історія української літератури. Народна творчість. - Авгсбург, 1947. - 368 с.

2. Білещъкий $\Lambda$. Три сильветки: Марко Вовчок, Ольга Кобилянська, Аеся Українка. - Вінніпег, 1951. - 127 с.

3. Ільнщщький М. Критики і критерії: Аітературно-критична думка в Західній Україні 20 - 30-х рр. ХX ст. Аьвів, 1998. - С. 32-51.

4. Ільницький М. Аеонід Білецький - історик українського літературознавства // Білеиький $\Lambda$. Основи української літературно-наукової критики. - Аьвів, 1998. - С. 7-26.

5. Мандрика М. Аеонід Білецький. - Вінніпег, 1958. - 56 с.

6. Наєнко М. Амитро Чижевський і його “Історія української літератури” // Чижевський А. Історія української літератури (від початку до доби реалізму). - Тернопіль, 1994. - С. 3-15.

7. Романениук Б. Білецький Аеонід // Романенчук Б. Азбуковник: У 2 т. - Т 1. - Мюнхен, 1976. - С. 342-345.

8. Шевченківський словник: У 2-х т. - Т.1. - Київ, 1976. - 415 с.

\section{REFERENCES}

1. Biletskyi, L. (1947). Istoriia ukranskoi literatury. Narodna tvorchist. Avsburg, 368. [in Ukrainian]

2. Biletskyi, L. (1951). Try sylvetki: Marko Vovchok, Olga Kobylianska, Lesia Ukrainka. Vinnipeg, 127. [in Ukrainian]

3. Ilnytskyi, M. (1998). Krytyky i kryterii: literaturno-krytychna dumka v Zachidnii Ukraini 20-30-ch rr. XX st. Lviv, 32-51. [in Ukrainian]

4. Ilnytskyi M. Leonid Biletskyi - istoryk ukrainskoho literaturoznavstva. In L. Biletskyi (1998). Osnovy ukrainskoi literaturno-naukovoi krytyky. (pp. 7-26). Lviv. [in Ukrainian]

5. Mandryka, M. (1958). Leonid Biletskyi. Vinnipeg, 56. [in Ukrainian]

6. Naienko, M. Dmytro Chuzhevskyi i yoho "Istoriia ukranskoi literatury. In D. Chuzhevskyi. (1994). Istoriia ukrainskoi literatury (vid pochatkiv do doby realizmu).(pp. 3-15). Ternopil. [in Ukrainian]

7. Romanenchuk, B. (1976). Biletskyi Leonid. In B. Romanenchuk. Azbukovnyk. (Vol. 1-2. Vol.1). (pp. 342-345). Miunkhen. [in Ukrainian]

8. Shevchenkivskii slovnik (1976). (Vol. 1-2. Vol.1). Kyiv, 415. [in Ukrainian]

Отримано 21 травня 2019 р.

М. Івано-Франківськ

\section{ㅁㅁㅁㅁㅁㅁ}

MIHICTEРСТВО ОСВІТИ I НАУКИ УКРАÏНИ

ІНСТИТУТ ЛІТЕРАТУРИ ІМ. Т. Г. ШЕВЧЕНКА НАН УКРАЇНИ

ДНІПРОВСЬКИЙ НАЦІОНАЛЬНИЙ УНІВЕРСИТЕТ

IMЕНІ ОЛЕСЯ ГОНЧАРА

Запрошуємо взяти участь у роботі

IV Всеукраїнської наукової конференції

“НЕЛОЖНИМИ УСТАМИ” ПРО СВІТ І ЛЮДИНУ У СВІТІ”,

присвяченої 95-річчю від дня народження Павла Загребельного, проведення якої планується на 24-25 жовтня 2019 р.

в Дніпровському національному університеті імені Олеся Гончара

Основна проблематика конференції: Україна, свобода, мистецтво, людина як концепти життя і творчості П. Загребельного; Історичні романи письменника - "своєрідна літературна парабола" сучасності; Митець і влада: П. Загребельний, історія, сучасність; П. Загребельний і шістдесятники та дев'ятдесятники.

Робочі мови конференції - українська, російська, англійська.

Форма участі в конференції

1. Виступ із доповіддю на пленарному засіданні (до 15 хв.).

2. Виступ із доповіддю на секційному засіданні (до 10 хв.).

3. Участь у конфреренції без доповіді (у форматі “стенду").

4. Публікація статті.

Для участі в конференції просимо надіслати до 1 вересня 2019 р. на електронну адресу kedich.t1984@gmail.com:

1) заявку на участь у конференції;

2) електронний варіант статті (6-15 сторінок, у форматі *.doc, *.docx) та ін.

Захід організовано кафедрою української літератури Дніпровського національного університету ім. Олеся Гончара. 